Article

\title{
Unequal Higher Education in the United States: Growing Participation and Shrinking Opportunities
}

\author{
Barrett J. Taylor ${ }^{1, *}$ and Brendan Cantwell ${ }^{2}$ \\ 1 Department of Counseling and Higher Education, University of North Texas, Denton, TX 76203, USA \\ 2 Department of Educational Administration, Michigan State University, East Lansing, MI 48824, USA; \\ brendanc@msu.edu \\ * Correspondence: barrett.taylor@unt.edu; Tel.: +1-940-565-3238
}

Received: 25 July 2018; Accepted: 13 September 2018; Published: 18 September 2018

\begin{abstract}
This paper argues that rising institutional inequality is a component of individual-level inequality in the United States because U.S. higher education provides a diverse group of students with unequal access to different kinds of institutions. Using latent profile analysis, we classified all public and private nonprofit higher education institutions in the U.S. from 2005 to 2013 into seven categories. We held these categories stable over time and allowed institutions to move between them. "Good value" institutions were scarce and tended to limit access through selective admission. Only Subsidy Reliant institutions that were directly supported by government appropriations regularly provided good value seats to a racially diverse group of students. Yet the number of institutions in the Subsidy Reliant category declined markedly over time. The resulting system offered access to many students but provided limited opportunity to secure a good value seat.
\end{abstract}

Keywords: institutional stratification; high participation system; race in the U.S.; inequality of outcomes; politics of higher education

\section{Introduction}

Countries with sufficient resources tend to develop high participation systems of higher education (Cantwell et al. 2018; Marginson 2016a). By definition, such systems enroll a large share of the population in postsecondary education (Trow 1974). To some extent, growing participation is driven by the (real or perceived) economic benefits of higher education in the form of higher wages and improved standard of living (e.g., McMahon 2009). Primarily, however, a high participation system rests on a social rather than an economic basis (Schofer and Meyer 2005). In high participation systems, the chance to enroll in higher education becomes taken-for-granted. The number of students swells because it becomes normative - even obligatory—to pursue higher education (Cantwell et al. 2018; Marginson 2016b).

There are good reasons for enrollment in higher education to become a social expectation. Participation expresses a family's desire for a better life. Higher education offers the promise of not only wage growth and upward mobility, but also of social status and a stronger voice in civic life (Allen 2016; Cantwell et al. 2018; Labaree 1997). A high participation system offers many people a chance at this enriched life. Expanding access to higher education is therefore an urgent policy priority even if it is not directly associated with economic gain.

Additional urgency comes from the contingency of social arrangements. Once a high participation system is established, it—like all social systems—must be reinforced and maintained (Fligstein 2001; Zietsma and Lawrence 2010). Following a model typical of not-for-profit ventures (Winston 1999), high participation systems of higher education are undergirded by public trust (Margsinon 2012). Students and families trust that higher education provides a passport to a better life, both socially and 
economically, which sustains the expectation that everyone will attend. In order for high participation systems to endure, this public trust must be maintained.

Increasingly, however, the link between higher education participation and a better life is not straightforward. As Piketty (2014) and his colleagues (e.g., Piketty and Saez 2003) ${ }^{1}$ have documented, economic inequality has widened in many of the same national systems that have expanded higher education participation. Despite the promise that higher education offers a passport to a more prosperous and fulfilling life, in many countries, growing participation and widening inequality in life outcomes have occurred simultaneously. How can a high participation system both provide large numbers of students with access to education and contribute to wildly unequal social outcomes?

Stratification of systems into higher and lower value places is one potential answer to this question. Not all enrollment destinations are created equal. High participation systems produce access, meaning that large numbers of seats are generally available. However, producing a large number of total seats is no guarantee that a system will generate adequate numbers of highly desirable opportunities. Indeed, on balance, high-value seats are scarce (Marginson 2006). As such, a high participation system can produce adequate access-meaning total number of seats relative to the pool of potential students-without generating sufficient opportunity by providing abundant "good value" seats. We considered a seat to offer "good value" when it provides trusted education without imposing too high a cost relative to its social position. Relative cost refers not only to the tuition price a student pays but, more importantly, to the share of educational expenses covered by tuition fees.

Of course, there are many other ways to measure whether a seat offers "good value." For example, we might explore the expected wage returns for a student admitted to a particular institution. This approach has become widely popular in higher education studies and tends to assume the primary purpose of higher education is to secure a return on investment. Yet determining what social factors lead to greater individual wage returns is fraught (Marginson 2017). Institutional selectivity (Thomas 2003), field of study (Webber 2014), and the social characteristics of students (Brand and Xie 2010) all contribute to future earnings. Social and individual factors interact. Observed effects of institutional selectivity all but vanish when controlling for pre-college academic performance, which is strongly correlated with social class among White students. By contrast, Black and Latinx students see substantial gains from institutional selectivity even after taking their academic credentials into account (Dale and Krueger 2011). What is more, simple descriptive analysis shows that, as the labor market becomes saturated with degree-holders, the median wage for someone with a college degree begins to approach the overall median wage. "In the early 1990s, the typical worker with a baccalaureate degree or above earned between 80 and 90 per cent more than the typical worker overall (median wage earner among all workers). By the mid-2010s the typical college-educated worker earned just under 70 per cent more than the typical worker overall... The typical college educated worker retained a wage advantage over the working population but that advantaged declined meaningfully" (Cantwell 2018, p. 257). Finally, an approach that focuses on individuals' wage premiums ignores the many non-monetary benefits of higher education. Education is intrinsically rewarding, and produces a variety of benefits such as greater civic participation that are not easily quantified (Allen 2016). For these reasons, we do not define "value" in terms of expected wages or other post-completion rewards.

Instead, we define a "good value" seat by emphasizing the education students experience relative to the financial contribution they are expected to make. Specifically, we deem a seat as of good value when the institution spends at a fairly high level and does not rely on tuition fees to cover too much of that spending. While terms like "fairly high" and "reasonable" are imprecise, we view this as a strength that allows our definition to be fitted to the details of a particular national system of higher education. Higher education offers both difficult to measure individual financial returns and intrinsic rewards, as well as broad social or community benefits. Hence, we are concerned with considering

1 Piketty and Saez provide historical data on income inequality in the United States. The study was published in article format by the Quarterly Journal of Economics in 2003. Updated data are available on Emanuel Saez's website: https: / / eml.berkeley.edu/ saez/. 
the conditions that provide a rich educational environment that reasonably stands to return benefits relative to the share of the cost students are expected to cover. In doing so, we assume the cost of education on a per-student basis is a reasonable proxy for the richness of an educational experience. Two institutions may offer education at similar levels of per-student expenditure but one uses student fees to cover a quarter of total spending and the other uses fees to cover two-two thirds. In such a case, we consider the former institution to be a better value than the latter. We think this approach is realistic about what can be measured consistently over time, while also taking account of the relative attractiveness of a particular enrollment destination (given the mixture of available alternatives).

Institutions that provide good value seats to a large group of diverse students expand the supply of aggregate student opportunity. In the current U.S. context, however, opportunities are not randomly distributed. High-status enrollment opportunities are more likely to be won by students from socially and financially privileged households (e.g., Posselt et al. 2012). In the U.S., this means that students at good value institutions tend to be wealthier and more likely to identify as White than is the total population of students. This concentration of already-advantaged students at top institutions means that the allocation of high value seats tends to solidify existing inequalities rather than provide opportunities for social mobility. Indeed, rates of inter-generational mobility have stagnated in the United States. Whereas the large majority of people born in the 1940s could expect a higher income and better standard of living than their parents enjoyed, among those born in the 1980s only half experienced upward mobility (Chetty et al. 2017a). Degree holders earn more than non-graduates on average, yet rates of mobility are modest even among graduates. Students who attended highly selective "Ivy-Plus" institutions generally earned high wages but did not typically travel great social distances because they tended to originate in the upper income brackets; elite private institutions enroll very few low-income students. Community colleges and broad access universities such as the California State University campuses enroll more low-income students but graduates of these places are much less likely to become high-earners (Chetty et al. 2017b). Students were better off for attending, but most were not as well off as they would have been had they secured a high value seat. In other words, expanding access to-and participation in-higher education can alleviate and heighten inequality at the same time (Marginson 2016a).

Because student opportunity and social stratification are connected through the scarcity of high-value seats, there is a crucial organizational dimension to access to higher education. There is a finite number of possible colleges and universities that a student might attend at a given point in time. The exact mix of available institutions-how much they spend per student, how many students each enrolls, and so on-describes the aggregate opportunity available at a particular moment. When there are many desirable seats relative to the number of enrollees, opportunity is abundant because the inventory of available institutions offers many good value seats. When there are fewer good value seats, opportunity is scarce, even if access - the chance to go somewhere-is provided. This decline in opportunity would occur not because of changes in student behavior, but due to organizational dynamics of the higher education system. The mixture of available colleges and universities has changed over time.

In this paper, we document just such a constriction of student opportunity by mapping changes in the field of available enrollment destinations in the United States. This shift in the landscape of available colleges and universities is particularly worrisome as increasing numbers of students enter U.S. higher education every year (NCES 2017). With growing numbers of students pursuing higher education, any reduction in available opportunity will be magnified because ever more individuals are competing for ever-fewer desirable seats. We therefore contend that our analysis contributes important new insights to the familiar topics of institutional stratification, access to higher education, and inequality of student outcomes.

The purpose of this paper is to explore the organizational dimension of higher education stratification in the U.S. context. We selected the U.S. because it was the world's first high participation system (Trow 1974). Accordingly, the U.S. provides a great deal of access to higher education. 
Total enrollments have swelled over time (Thelin 2011). Even as a mature system, public and non-profit baccalaureate-granting institutions in the U.S. add about 200,000 new students per year (NCES 2017). ${ }^{2}$ Many students have the chance to enroll somewhere.

At the same time, however, greater participation in higher education has not necessarily made U.S. society more equal. Income and wealth inequality have grown explosively since the 1970s, which is the same decade when higher education participation soared (Piketty 2014). In other words, social stratification and higher education participation increased simultaneously. Higher education institutions in the U.S. are also steeply unequal. Some of this inequality was designed by public policymakers who sought to balance high participation, research eminence, and affordability by hierarchically differentiating public systems (Douglass 2000; Marginson 2016b). Indeed, by some measures such as total spending, institutional inequality in the U.S. has always been high (Lau and Rosen 2016). The U.S. features both a hierarchically differentiated system of higher education institutions and high levels of individual- and household-level inequality. These are the conditions of limited educational opportunity amid high levels of access.

Despite long having high levels of institutional inequality, there are reasons to think that institutional inequality in the U.S. has become even more pronounced over time. Virtually all U.S. colleges and universities confront chronically rising costs (Archibald and Feldman 2011). Rising costs prove particularly problematic when revenues are variable or in decline because under such conditions increased costs result in much higher tuition prices for students. Rising costs and volatile revenue are the precise set of conditions facing most U.S. institutions. As on the individual level, the distribution of institutional revenues and wealth is highly asymmetric. A small handful of institutions capture the vast majority of revenues from investments (Cantwell 2016; Weisbrod et al. 2008) and research (Taylor 2016). Direct government support, which once helped to blunt these inequalities, has retreated notably since 2008 (SHEEO 2018). This retreat has exposed large numbers of higher education institutions to the financial perils of rising costs and uncertain revenues. The likely consequence is a sharp decline in the value of seats at the institutions that are most exposed to fiscal pressures.

This change in the mixture of available enrollment destinations has limited opportunity for students even as access has expanded. What is more, this constriction of opportunity appears to fall most heavily upon traditionally underserved students, especially Black Americans. The result is that higher education in the U.S. has become more unequal at the same time that total participation has grown

\section{Conceptualizing Institutional Inequality in the U.S.}

There is no single measure of institutional inequality, nor does the existing literature provide consensus on how to conceptualize or quantify it. Each institution of higher education is situated in a broader social field (Fligstein and McAdam 2012). To describe institutional inequality and its consequences for students, it is necessary to construct an omnibus measure of field position. We do this by conceptualizing inequality in two dimensions: vertical (hierarchical) and horizontal (differentiation of type) position. We then identify two resources-money and students-for which institutions compete in vertical and horizontal spaces.

\subsection{Vertical and Horizontal Positions}

We understand vertical position as an indicator in which more is unambiguously better. From an institution's perspective, it is almost always better to have more money and greater demand for

2 Total higher education enrollments fluctuate, often counter to the business cycle. As of this writing, total enrollments are down from peaks during the years immediately following the Great Recession of 2008. Declining overall enrollments resulted from declines at community colleges and for-profit colleges. The non-profit liberal arts sector of the system has also seen some enrollment declines, but overall the public and non-profit "four-year" has grown steadily, which may reflect students seeking better value opportunities in higher education as the labor market improves. 
admission (Winston 1999). Institutions establish clear advantage over competitors by amassing more resources. When large numbers of students demand seats, budgets are ample, and the endowment grows, an institution enjoys an advantageous position in vertical space.

Horizontal position, in contrast to vertical, reflects the historical differences in mission that characterize higher education institutions in the U.S. (Morphew 2009). Higher education institutions engage in multiple enterprises simultaneously such as instruction, research, and service (Leslie et al. 2012). Different institutions balance these activities in different ways. There is no one mix of activities that is inherently preferable to another. Institutions that emphasize research are not inherently "better" at higher education than are those that focus on teaching.

While we cast vertical and horizontal positions as analytically distinct for convenience, in reality, the two often overlap. Consider the case of universities that emphasize research. Research is costly because it requires specialized equipment, expensive materials, and highly skilled personnel (Archibald and Feldman 2011). Accordingly, a research university will almost always generate and spend more money than an institution of comparable size that emphasizes teaching. What is more, a research focus allows an institution to compete for global status as well as local and national position (Marginson 2016c), thereby opening status competitions to the research university that are closed to its teaching-focused counterpart. A research-focused mission can be charted horizontally but can also enhance vertical position by attracting students from around the world and by securing the financial resources necessary to conduct research.

As this illustration suggests, vertical and horizontal positions are not wholly independent of one another. A research university can likely attain a higher vertical position than a teaching-focused institution because of their differences in horizontal positions. The lofty heights attained by the most successful research universities are all but closed to institutions that emphasize teaching.

While vertical and horizontal positions are not wholly distinct, then, neither are they dependent upon one another. It is likely that some teaching-focused institutions attain higher vertical positions than do some research universities. ${ }^{3}$ By maintaining small enrollments, a teaching-focused institution could spend more generously on each student than does a larger research university. In this way, the smaller institution might generate more demand for admission to its good value seats, thereby improving its vertical position by admitting a smaller percentage of applicants than does a moderately selective research university. Vertical and horizontal positions are not wholly distinct from one another, but they combine in enough different ways that it is important to focus on each as we seek to map institutional inequality in the U.S.

\subsection{Students and Money}

As noted previously, the basis of a high participation system is social (Cantwell et al. 2018). To say that a system is social does not imply that it is immaterial or "merely" cognitive. Social systems require resources to function (Friedland and Alford 1991); rules and practices do not sustain themselves, but require continual reproduction and reinforcement (Fligstein and McAdam 2012; Zietsma and Lawrence 2010). Perhaps no resources are more central to this process of reproduction than students to enroll and money to spend.

While higher education institutions in the U.S. espouse a wide variety of missions (Morphew 2009), virtually all engage in some instruction (Weisbrod et al. 2008). Accordingly, all institutions need at least some students. Further, in the U.S. system, students represent money. This is because almost all institutions in the U.S. system have long charged tuition fees (Thelin 2011). Many private not-for-profit institutions rely heavily on these funds to maintain their basic operations (Breneman 1994; Taylor and Morphew 2013; Weisbrod et al. 2008; Winston 1999). Even public

3 Elite liberal arts colleges, that are well-endowed and highly selective, enjoy prestige in U.S. higher education. The presence of elite teaching-focused institutions is peculiar to the American system. 
institutions increasingly rely on tuition fees, with a growing number of government-funded campuses drawing more than half of their budgets from students' payments (SHEEO 2018). Students in the U.S. therefore represent both human and financial resources. Students are crucial to higher education institutions in the U.S. because they are a basis of status, reflect mission, and provide necessary income.

As outlined previously, it is important to understand competition for students as occurring in both vertical and horizontal dimensions. Vertical positions are those in which more is unequivocally better. With respect to students, the best indicator of vertical position is admission selectivity. Carefully selecting which students to admit is a clear signal of institutional status because it indicates high demand for admission and the scarce opportunity to secure a good value seat (Marginson 2006; Winston 1999). For this reason, admission selectivity is a key indicator of an institution's position in a national system (Marginson 2016c).

In horizontal space, a range of possible positions can yield similar vertical results. These positions are different but not necessarily better than one another. With respect to students, the best indicator of horizontal position is total enrollment. Two campuses may grow to many different sizes with the same level of admission selectivity if one receives far more applications for admission than does the other. Further, different enrollment sizes confer different benefits. A smaller campus can increase spending per student more easily than can a large one, thereby enhancing the value of each individual seat. However, a large campus can capitalize on efficiencies of scale, thereby generating slack resources to subsidize preferred operations. The different benefits available to institutions of different sizes help to explain the longstanding institutional diversity of U.S. higher education (Harris 2013). Some level of horizontal diversity is observed in all high participation systems but it is particularly acute in the U.S. In most systems, virtually all of the most desirable seats are found in research universities. In the U.S., however, elite liberal arts colleges—small institutions that focus intensively on undergraduate teaching-are about as selective as the leading research universities. To be sure, there is a practical limit on the possibility to achieve vertical position through distinctive horizontal position. Vertical and horizontal dimensions are not wholly independent of one another, and the most elite institutions in the system, unrivaled in their status, are highly-selective private research universities that maintain smaller undergraduate enrollments than their public counterparts (Cantwell et al. 2018). Nonetheless, the existence of small, high-status, teaching-focused institutions mandates the inclusion of a measure of horizontal position in the competition for students. No liberal arts college rivals Harvard for status, but several colleges reach the top of a local hierarchy whose apex approaches or exceeds even the most prestigious public research universities.

Higher education institutions in the U.S. compete for money as well as students. The importance of money is self-evident. Funds must be expended to hire staff and maintain facilities. What is more, the amount of money needed to sustain a higher education institution grows annually as costs rises (Archibald and Feldman 2011). Higher education in the U.S. is highly decentralized. While governments provide direct support for many public colleges and universities, the amount of that support has declined over time (Barringer 2016). Increasingly, money is secured through competitions rather than via direct support (Slaughter and Rhoades 2004). Reliance on fee and other income earned competitively is especially important on a per-student basis. As state funding receded, enrollments continued to grow.

In vertical space, more is better. A vertical measure of financial position therefore would indicate something like total financial resources. By such measures, U.S. institutions have been dramatically unequal for a long time (Lau and Rosen 2016). Because our interest is the relationship between organizational dynamics and student opportunity, it is important to allocate these resources per student. This simple act of division allows us to calculate the value of a seat rather than the scale of an institution. The University of Central Florida, with over 55,000 students, has a larger budget than tiny (approximately 1,500 students) Swarthmore College. However, Central Florida's larger budget does not indicate superior vertical standing; for the individual student, spending per seat matters more 
than total spending. Accordingly, total spending on education and related (E\&R) activities per student is a useful indicator of an institution's vertical financial position.

One horizontal position is not necessarily preferable to another. Higher education institutions in the U.S. gather revenues from many different sources. Funds may come from students' own tuition payments, from governments, from donations, or from investments and other commercial activities (Weisbrod et al. 2008). Whereas spending more money per student is clearly better than spending less, it is less clear whether deriving revenues from one source is superior to gleaning them from another. This has not always been the case. For decades, direct government support was seen as a steady, reliable source of revenue that insulated institutions from the volatility of competitions (Slaughter and Leslie 1997). As direct government support declined, however, it became less clear that reliance on public support in the U.S. was preferable to dependence upon tuition, donations, or other sources of revenue. Given the various ways institutions gather income, the sources from which revenues are derived is a useful indicator of horizontal financial position.

\subsection{Institutional Inequality and Student Opportunity}

We have conceptualized institutional inequality along four axes, two vertical (selectivity, educational spending per student) and two horizontal (total enrollment, source of revenues). This conceptualization allows us to estimate the value of a seat at a given institution in a particular year. By combining all of these estimates into a single measure, we can map the landscape of available institutions—-that is, aggregate student opportunity—at various points in time.

In order to address pressing public policy questions about inequality of opportunity, it is also crucial to know which students have access to which groups of institutions. As with institutional inequality, there are many ways to measure individual level opportunity. High value seats can be allocated unequally on the basis of social class, gender identification, sexual orientation, religion and language - and, indeed, this is often the case. In the U.S., however, racial identification has long played an outsized role in the unequal allocation of social opportunity (Anderson 2016). The first colleges and universities in the U.S. were steeped in racism. Curricula justified white supremacy, slave labor built classrooms, and academic staff actively participated in the expansion of colonial domination over Native lands (Wilder 2013).

Despite centuries of change, higher education in the U.S. has remained deeply enmeshed with racial inequality. Highly selective campuses that offer good value seats disproportionately over-represent White students (Posselt et al. 2012). Experiences on campus also differ markedly by race. Almost all higher education institutions in the U.S. graduate a higher percentage of White students than Black or Latino students (Nichols and Evans-Bell 2017). The oldest institutions in the country are both more likely to have benefited from the exploitation of Native lands and slave labor and to enjoy prestigious reputations from the accumulation of financial and social capital. Consider the case of Georgetown University, an elite private research institution located in the District of Columbia. The Jesuit order of the Catholic Church, which still controls Georgetown, used the proceeds from the sale of African slaves to secure the university's financial position in its early history. While Georgetown has recognized its past by offering preferred admission and scholarships to the descendants of the slaves who were sold to establish the institution (Belkin 2016), the students who attend Georgetown and enjoy associated opportunities remain largely affluent and White.

Of course, students' racial identification is not the only way to study inequality. Socioeconomic status, immigration status, and gender identity also mark major power asymmetries in the U.S. and beyond. That said, the salience of race in U.S. higher education is impossible to overstate. As outlined by the President's Commission on Slavery and the University (2018) at the University of Virginia, racism has characterized higher education in the U.S. in operations ranging from the use of slave labor to the procurement of cadavers for medical students. These grisly details are a fact of U.S. higher education and must be confronted in any analysis of power and inequality. While there are many important ways to view unequal student opportunity, in the U.S. context, it is difficult to study 
individual inequality without directly confronting racial inequality. We hope that future researchers will supplement our work by considering inequality along other axes including, but not limited to, socioeconomic status.

\section{Data and Method}

As conceptualized above, our understanding of institutional inequality is multi-dimensional. We are less interested in measuring inequality along one of the four axes we have identified than in understanding how these four factors jointly identify a seat that is more or less valuable. In other words, we do not simply want to consider one of these factors at a time, but to understand all four of them simultaneously in order to generate a robust, multi-dimensional picture of institutional inequality.

To do this, we used latent profile analysis (LPA), which we estimated in MPlus 6.0 software (Geiser 2013; Muthen and Muthen 2011). This statistical technique identifies groups of observations that can be intuited conceptually but cannot be measured directly, and is well suited to analyses that are centered upon analytically distinct subgroups that are included within a single sample. We used measurable indicators to identify these latent profiles. By selecting measures that conformed to the four axes of the conceptual model identified previously, we were able to categorize U.S. institutions into groups based on their financial and enrollment characteristics along both horizontal and vertical dimensions (Masyn 2013). Further, by observing each institution annually and counting a unique observation as an institution-year (i.e., institution $i$ observed in year $t$ ), we were able to map changes over time in the available suite of institutions.

The U.S. federal government collects data on higher education institutions through the Integrated Postsecondary Education Data System (IPEDS). We used data directly from IPEDS on public institutions and IPEDS data that had been standardized by the Delta Cost Project for private not-for-profit institutions. Our sample included all public and private not-for-profit institutions that awarded a four-year degree. We observed these institutions for the years 2005-2013 in order to understand how the mixture of available seats changed during and after the recession.

We fit our LPA using variables that corresponded to the four axes of our conceptual model. To measure vertical position in competition for students, we included the percentage of applicants granted admission. Horizontal position in competition for students was indicated by total full-time equivalent (FTE) enrollment. We measured vertical financial position using education and related (E\&R) spending per FTE. Because virtually all U.S. institutions enroll students and the vast majority of them collect tuition fees (Weisbrod et al. 2008), we included the percentage of E\&R spending derived from tuition as a measure of horizontal financial position.

As in any inferential quantitative analysis, determining model fit is crucial. Estimating the LPA began with a single category. We then re-estimated the model with two categories and compared the two sets of results using a variety of goodness-of-fit tests. We continued in this manner, adding one additional category with each new estimation, until arriving at a set of results that did not improve meaningfully over a more parsimonious model. This preferred set of results classified all sampled institutions into seven categories. Classifications were made with a high level of confidence. The mean probability of the likeliest profile assignment was $91.7 \%$ (97.9\% median), indicating that, in almost all cases, the seven-category LPA proved precise.

Once institutions had been classified into latent profiles, we overlaid these institutional categories with data on enrolled students. This allowed us to understand the racial dynamics of opportunity in a system where participation was rising alongside institutional inequality. Averages for a particular profile were compared to the sample average using t-tests to determine whether institutions in a given category provided more or less access to students of color than did the average sampled institution. 


\section{Findings}

\subsection{Institutional Inequality in the U.S., 2005-2013}

Our LPA identified seven categories of higher education institutions in the U.S. We describe the financial characteristics of these seven categories in Figure 1 and the student characteristic in Figure 2. In each figure, a profile's average observed value has been divided by the sample average to generate a ratio. This ratio allows us to compare each category to the sample average. We then subtracted one from each ratio for ease of interpretation. A value of 0.1 on E\&R spending per student, for example, would indicates that the average institution in the category spent $10 \%$ more than the average institution found in the sample as a whole. A value of -0.2 on admission selectivity would indicate that the average institution in a profile was $20 \%$ less selective than the average sampled institution. Real values and comparisons to the sample average can be found in Tables 1 and 2 . Table 1 includes institutions that offer good value seats while Table 2 consists of institutions that offer less attractive enrollment destinations.

Table 1. Profiles offering good value seats.

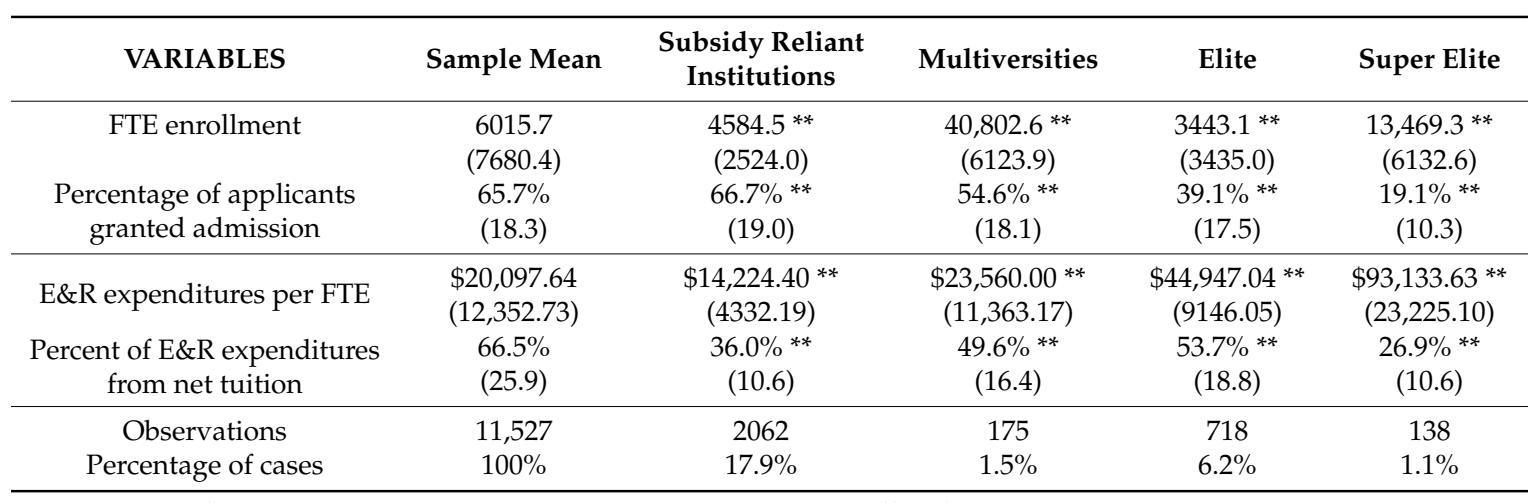

Results of "two-tailed" $t$-tests indicating whether group mean differs from sample mean depicted as ${ }^{* *} p<0.01$

Table 2. Profiles offering less desirable seats.

\begin{tabular}{ccccc}
\hline VARIABLES & Sample Mean & $\begin{array}{c}\text { Vulnerable } \\
\text { Institutions }\end{array}$ & $\begin{array}{c}\text { Smaller Typical } \\
\text { Universities }\end{array}$ & $\begin{array}{c}\text { Larger Typical } \\
\text { Universities }\end{array}$ \\
\hline FTE enrollment & 6015.7 & $2486.2 * *$ & $13,617.2 * *$ & $24,800.2^{* *}$ \\
& $(7680.4)$ & $(1877.6)$ & $(2832.9)$ & $(3624.3)$ \\
Percentage of applicants & $65.7 \%$ & $69.1 \% * *$ & $68.7 \% * *$ & $64.6 \%$ \\
granted admission & $(18.3)$ & $(14.6)$ & $(16.2)$ & $(16.9)$ \\
\hline E\&R expenditures per FTE & $\$ 20,097.64$ & $\$ 18,771.90 * *$ & $\$ 14,863.94 * *$ & $\$ 17,794.74 * *$ \\
Percent of E\&R expenditures & $(12,352.73)$ & $(5378.21)$ & $(5424.89)$ & $(7676.47)$ \\
from net tuition & $66.5 \%$ & $82.3 \% * *$ & $53.6 \% * *$ & $52.9 \% * *$ \\
Observations & $(25.9)$ & $(17.9)$ & $(21.2)$ & $(19.1)$ \\
\hline Percentage of cases & 11,527 & 6613 & 1179 & 642 \\
\hline
\end{tabular}

Results of "two-tailed" $t$-tests indicating whether group mean differs from sample mean depicted as ** $p<0.01$

LPA identifies discrete categories but, as in any social scientific analysis, investigators are responsible for interpreting results. For analytic convenience, we named each category. Category names are: (1) Vulnerable institutions; (2) Subsidy Reliant institutions; (3, 4) Typical Universities, Larger and Smaller; (5) Multiversities; (6) Elite colleges and universities; and (7) Super Elite universities. We explain the rationale for these names and briefly describe each of these institutional types below.

Vulnerable institutions were the lowest-status group. They were also the most numerous of all institutions, comprising a little more than half of the sample. This category was overwhelmingly but not exclusively private $(97.4 \%)$, and its characteristics indicated that these privates were far more likely 
to be anonymous than well-known. Indeed, we termec these institutions Vulnerable because of their limited financial resources and low prestige. The average Vulnerable institution spent very little per student, relied heavily on tuition fees, and admitted almost all applicants (see Table 2). Such institutions helped to absorb demand in a high participation system, but appeared to have little ability to generate demand for seats at their own campuses. Such campuses were Vulnerable because, should aggregate demand fall or better value seats open up, it was unclear how these institutions would continue to exist. Limited demand reflected the fact that Vulnerable campuses provided low-value seats where students paid high tuition fees $(\$ 18,771.90 \mathrm{E} \& \mathrm{R} \times 82.3 \%$ from tuition $=\$ 15,449.27$ average per FTE payment) in return for low educational spending.

Subsidy Reliant institutions mirrored their Vulnerable counterparts in some respects. Institutions in both categories were small, nonselective, and low-spending (see Tables 1 and 2). Indeed, Subsidy Reliant institutions spent a little less per student than did Vulnerable campuses, though Subsidy Reliant institutions spent far more overall because they enrolled nearly 2000 more students. The most glaring difference between institutions in the two profiles, however, was the source of revenue. Vulnerable institutions drew more than $80 \%$ of educational spending from students' own tuition fees. Indeed, Vulnerable institutions were so heavily reliant on tuition fees that they biased the sample average upward dramatically; no other profile was even average on tuition reliance (see Figure 1). Subsidy Reliant institutions, by contrast, drew on other sources such as government support ( $87 \%$ of Subsidy Reliant institutions were public). Non-fee income minimized the importance of tuition to fund core operations at Subsidy Reliant institutions. As a result, tuition reliance was the lowest of any group. The lack of reliance on tuition made Subsidy Reliant institutions attractive enrollment destinations. Although spending was low, so were tuition fees, a state of affairs that created good value seats.

As their name implies, the two groups of Typical Universities were about average on tuition reliance and admission selectivity (see Table 2). However, members of both categories were substantially larger than the sample average. Big total enrollments meant that spending per student was fairly low because the denominator was so high. Enrollment size was the primary factor that distinguished the two groups of Typical Universities from one another. Smaller Typical Universities were somewhat larger than the average institution, whereas Larger Typical Universities were much larger (see Figure 2). On balance, Larger Typical Universities were a bit better off than their smaller counterparts because greater scale enabled the generation and redeployment of slack resources. Allowing for this difference of degree rather than kind, however, members of the two categories were fairly similar. Typical Universities were primarily public ( $84 \%$ of Smaller, $89 \%$ of Larger) institutions, and their large enrollments enabled a system to accommodate high levels of participation. Because these institutions engaged in slightly below-average spending and approximately average levels of tuition reliance, seats at Typical Universities were of average value.

Multiversities were the largest campuses of all. More than $90 \%$ of Multiversities were public institutions; these are the archetypal U.S. public flagship universities with massive undergraduate enrollments and extensive research enterprises (Marginson 2016b). Indeed, public Multiversities were designed by state policymakers to sit atop the hierarchy of public higher education (Douglass 2000). Multiversities spent generously on their students and practiced fairly selective admissions. Tuition reliance was somewhat lower than at the Typical Universities, though far higher than at Subsidy Reliant institutions (see Table 1). Overall, then, Multiversities were some of the most prestigious campuses in the U.S. Their seats were of good value, and thus were in high demand. Multiversities admitted only half of applicants and still enrolled about 40,000 students on average.

Even the Multiversities paled next to Elite and Super Elite campuses. Members of these two top-shelf groups were exclusively private, and attained heights that even the best-funded public universities could not match. Elite and Super Elite institutions spent more, were less tuition reliant and were more selective than was the average institution (see Table 1). Yet it would be a mistake to think that the Elite and Super Elite were merely two variants of a type. The Super Elite exceeded the Elite on 
all measures. Members of both groups provided high-value seats, but seats at Super Elite campuses were far more highly coveted, as indicated by greater admission selectivity (see Figure 2).

Almost any student would rather attend a Super Elite, Elite or Multiversity campus-where spending is high and not funded exclusively by tuition-than a Vulnerable institution. The desirability of these institutions means that seats at them are relatively scarce. There are not very many Multiversities, Elite, or Super Elite institutions. Together, these three categories comprise less than 9\% of the sample. What is more, seats on these campuses are difficult to access. Many students want to be admitted. All three categories were, on average, more exclusive in their admission practices than was the sample as a whole. With few campuses and high admission standards, Multiversities, Elite, and Super Elite institutions provided good value seats to few students.

For these reasons, the U.S. system has traditionally provided Subsidy Reliant institutions in order to supply good value seats to large numbers of students. To borrow from the common vocabulary of higher education studies, Subsidy Reliant institutions balance equity with efficiency in the U.S. high participation system by providing large numbers of subsidized seats to students while at the same controlling educational costs. On these campuses, government funding allows a diverse array of students to enjoy the benefits of higher education while asking students to cover only a small portion of educational spending.

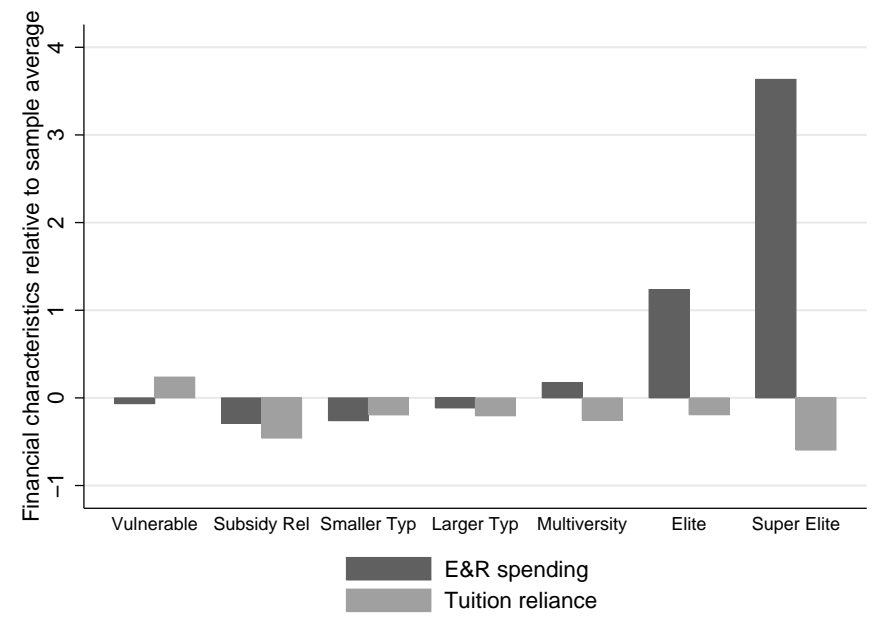

Figure 1. Financial characteristics of the seven profiles.

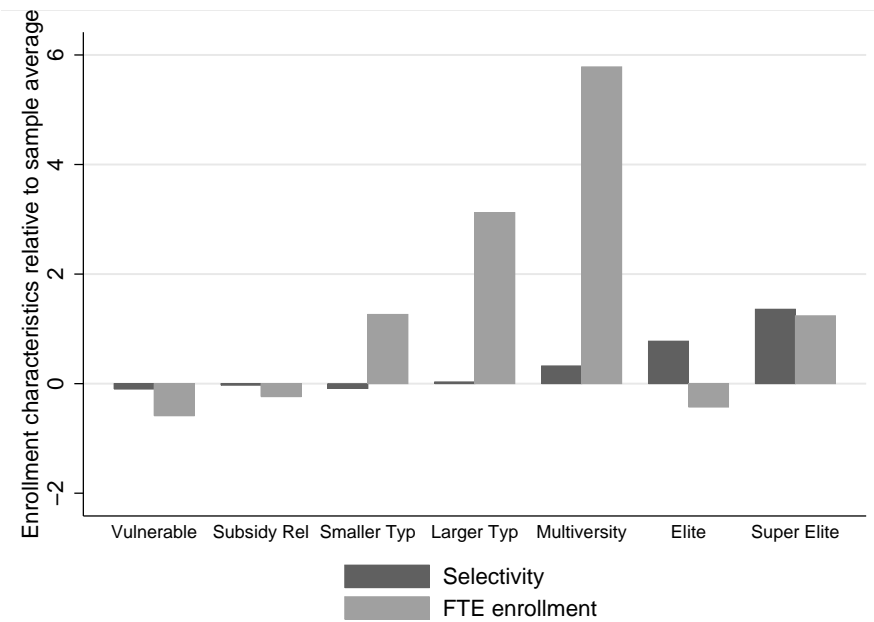

Figure 2. Enrollment characteristics of the seven profiles. 


\subsection{Institutional Inequality and Student Opportunity}

As illustrated above, seats at institutions in different categories-Vulnerable institutions, Multiversities, and so on-vary widely in value. Who goes where is therefore a central question for analysts interested in questions of access and opportunity in the U.S. system. For this reason, we turn our attention to the enrollment destinations of students who identified with different racial groups.

Data on enrollments by race are reported in Table 3. The IPEDS survey tracks many different racial groups, though almost certainly not enough to reflect the dynamic diversity of the U.S. population. Nonetheless, these data allow us to begin to understand the demographics of institutions that provide good value seats, and to compare those demographics to institutions that absorb demand but do not necessarily provide excellent value to students.

Table 2 classified Vulnerable institutions along with Smaller and Larger Typical Universities as institutions that provided less desirable seats than their good value counterparts. As Table 3 indicates, White students are represented at about an average rate in all three of the less desirable profiles. Native American students, by contrast, are underrepresented in all three profiles. In other words, White students have access to low and average value seats, while Native American students have more limited access to these modestly attractive enrollment destinations.

Additional disparities emerged across the three less desirable profiles. Black students are found at Vulnerable institutions at about an average rate. This means that Black students in the U.S. have relatively high access to the lowest value seats. By contrast, Black students are acutely underrepresented at average value Smaller Typical and Larger Typical Universities. Seats of better value, in other words, tend to be less likely to be allocated to Black students, thereby perpetuating the privileged racial demographics of higher status institutions.

Interestingly, the demographics of Latinx and Asian American students inverted this pattern. Latinx students are represented at an average rate at Vulnerable and Smaller Typical campuses, but are overrepresented at good value Larger Typical Universities. Similarly, Asian American students are underrepresented at Vulnerable institutions, represented at an average rate at Smaller Typical Universities, and overrepresented at the Larger Typical Universities. These findings likely reflect the concentration of large public institutions in racially diverse states such as California, Florida, and Texas. In other words, rates of representation for Latinx and Asian American students are likely more indicative of geography than of an absence of racism by administrators in these institutional types. Geography and racial discrimination interact to produce asymmetric patterns of access to good value seats. Student demographics at good value institutional types support this interpretation. Latinx students are underrepresented at institutions that provide the most valuable seats except for Multiversities, which also tend to be found in large, diverse states.

Table 3. Racial demographics of profiles providing low and average value seats.

\begin{tabular}{|c|c|c|c|c|c|c|c|}
\hline $\begin{array}{l}\text { Percentage of students } \\
\text { who identified as. }\end{array}$ & $\begin{array}{l}\text { Vulnerable } \\
\text { Institutions }\end{array}$ & $\begin{array}{c}\text { Subsidy } \\
\text { Reliant } \\
\text { Institutions }\end{array}$ & $\begin{array}{c}\text { Smaller } \\
\text { Typical } \\
\text { Universities }\end{array}$ & $\begin{array}{c}\text { Larger } \\
\text { Typical } \\
\text { Universities }\end{array}$ & Multiversities & Elite & $\begin{array}{l}\text { Super } \\
\text { Elite }\end{array}$ \\
\hline Black students & $13.2 \%$ & $19.0 \%$ & $9.4 \%$ & $8.5 \%$ & $4.8 \%$ & $10.5 \%$ & $6.7 \%$ \\
\hline Latinx students & $7.0 \%$ & $5.5 \%$ & $7.7 \%$ & $10.9 \%$ & $15.2 \%$ & $6.6 \%$ & $8.8 \%$ \\
\hline Asian American students & $2.6 \%$ & $1.7 \%$ & $4.0 \%$ & $9.3 \%$ & $14.4 \%$ & $10.5 \%$ & $18.0 \%$ \\
\hline
\end{tabular}

As the previous sentence implies, Black and Native American students are underrepresented at Multiversities, Elite, and Super Elite institutions. In other words, institutions in these highly desirable categories draw a meaningfully smaller proportion of their enrollments from these traditionally underserved racial groups than does the sample as a whole. Only Subsidy Reliant institutions provide good value seats to Black and Native American students at rates that are at or above the sample average. By enrolling a racially diverse group of students in good value seats, Subsidy Reliant 
institutions provide crucial sites of opportunity, thereby buttressing the public trust that undergirds a high participation system of higher education.

\subsection{The Opportunity to Succeed}

Access and opportunity are not synonymous with one another. As we use the terms, access means that a student has the chance to enroll somewhere while opportunity means that a student can secure a good value seat. Access is necessary but not sufficient to realize opportunity.

Thus far, we have primarily thought of access and opportunity as features of admission-where does a student go? It is important to remember however that the economic and social benefits of higher education are largely enjoyed by those who have a degree, and not those who participated and did not finish. Opportunity is therefore consolidated by graduation (McMahon 2018). The graduation rate in U.S. higher education is notoriously dismal. Among students who entered four-year colleges and universities in 2008, only 60\% graduated within six years (NCES 2017). Given the need to graduate in order to consolidate opportunity, we examined rates of completion throughout the U.S. system.

When considering graduation rates, we again found that opportunity was distributed asymmetrically. As shown in Figure 3, more than $90 \%$ of students who enrolled at Super Elite universities graduated within six years, as did greater than three-quarters of all students enrolled at Elite and Multiversity institutions. The average six-year graduation stood at approximately $60 \%$ among the Larger Typical Universities. Among the Smaller Typical universities and Vulnerable institutions, the average graduation rate was approximately 53\%, and only $44 \%$ among Subsidy Reliant institutions. The overall pattern was predictable and consistent with other findings. Institutions that were more selective and spent more per student boasted better rates of completion relative to the institutions that provided broad access and spent relatively less. While Subsidy Reliant institutions had the lowest average six-year graduation rate, they also practiced the most generous admissions and commanded the fewest resources on a per-student basis. In other words, Subsidy Reliant institutions provided such broad access and operated with such little slack that it was necessary to conceptually adjust assessments of their student outcomes. Since Subsidy Reliant institutions did not select on the probability of strong academic performance it is reasonable to expect lower rates of completion among these colleges and universities.

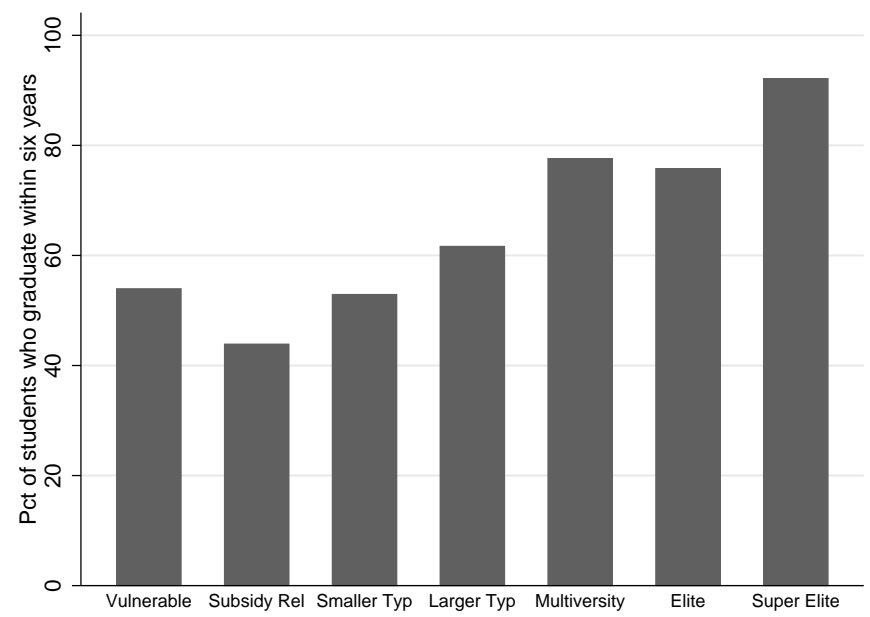

Figure 3. Average six-year graduation rate by institutional type.

Graduation rate, like access, is a useful but incomplete measure of opportunity. Within institutions, some students may be better served than others. The history of exclusion and discrimination (Wilder 2013), coupled with pervasive and ongoing bias (Ladson-Billings 1998) means that colleges and universities are often better prepared to support White students than they are able to support Black students. Given this context, one common equity metric used in the U.S. is the 
completion, or graduation, gap between Black and White students within institutions (see, for example, Nichols and Evans-Bell 2017). This measure indicates the difference in completion rates for students identifying as White and those identifying as Black at the same institution. Considering the completion gap helps to understand who has the opportunity to succeed within particular types of institutions.

Figure 4 reports the graduation gap among each of our seven institutional types in percentage points. At approximately five percentage points, the gap is narrowest among the Elite and Super Elite institutions. These colleges and universities carefully select students and achieve high overall rates of graduation. To put it another way, impressive outcomes are secured through exclusion; after all, Elite and Super Elite institutions did not enroll very many Black students (see Table 3) and all the students they enrolled had impressive academic credentials and were all but assured of success. The presence of any graduation gap at institutions with such carefully selected students may be reasonably interpreted as concerning.

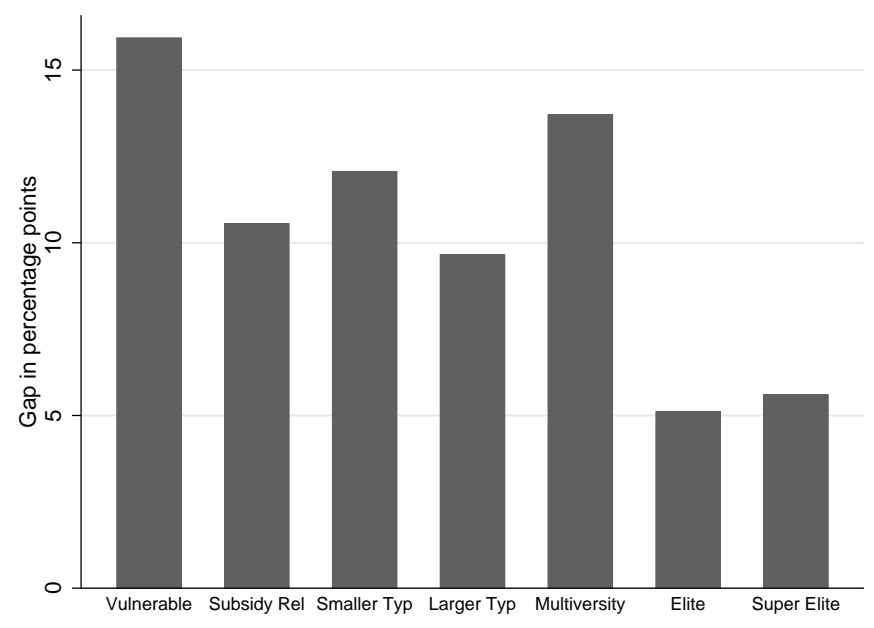

Figure 4. White-Black graduation gap (in percentage points) by institutional type.

Institutions in other categories produced wider completion gaps (see Figure 4). Vulnerable institutions graduated students at a higher overall rate than did Subsidy Reliant institutions. The completion gap tells a different story. The average gap in six-year graduation rates between White and Black students was approximately 16 percentage points among Vulnerable institutions, more than two percentage points higher than the sample average. This implies that Vulnerable institutions are not only poor value seats, but serve White students more fully than they serve Black students.

By contrast, the completion gap among Subsidy Reliant institutions is 10.5 percentage points, more than three points below the sample average. The completion gap at Subsidy Reliant institutions is similar to the Larger Typical, and lower than the Smaller Typical Universities. Not only do Subsidy Reliant institutions provide a good value education to students by offering low prices and large subsidies, but these institutions are also able to mitigate racial gaps in the opportunity to succeed when compared to other broad access institutional types. What is more, Subsidy Reliant institutions achieve these outcomes while enrolling a more diverse group of students than do the exclusive Elite and Super Elite institutions. At Subsidy Reliant institutions, more students are able to benefit from more equitable environments than in any other category of institution.

\subsection{Change over Time}

Thus far, we have presented results that pool data from all years. Yet meaningful historical changes happened between 2005 and 2013. Total participation swelled (NCES 2017), direct government support declined (SHEEO 2018), and investment returns and donations varied widely as a result of recession conditions (Desrochers and Hurlburt 2014). Amid such dramatic environmental changes, it would be surprising if the mixture of available institutions did not also change. 
Despite dramatic environmental changes, however, most profiles had fairly stable membership over time. Our analytic technique held categories constant over time but allowed individual institutions to move from one group to another. Yet most institutions began and ended the period in the same profile. To guard against the possibility of closures, mergers, or other events that could influence our analysis, change over time calculations reflect only institutions found in all nine years of the study. For all colleges and universities that appeared in each year from 2005 to 2013, the percentage of the sample that were Smaller Typical Universities (10.8-11.4\%), Larger Typical Universities (5.5-6.8\%), Multiversities (1.4-1.9\%), Elite (5.9-6.4\%), or Super Elite (1.1-1.2\%) changed hardly at all. The Vulnerable profile grew by many members but, because its membership was so large to begin with, the proportional change in membership was not great $(53.5-56.5 \%)$.

The most dramatic change over time was found in the Subsidy Reliant category, which declined from $21.8 \%$ of all cases to only $15.8 \%$. Even more dramatic declines are found when considering only public institutions. Subsidy Reliant campuses constituted an absolute majority of public institutions in 2005 (55.0\%). By 2013, the category had shrunk by almost one-third, and was no longer a majority of total publics $(40.4 \%)$. Of course, it is possible that institutions that remained in the Subsidy Reliant category grew their enrollments enough to continue providing the same number of good value seats in 2013 as they had in 2005. However, this was not the case. In 2005, public Subsidy Reliant institutions enrolled almost 1.2 million FTE students. By 2013, that figure had fallen to a little more than 734,000 FTE. In other words, the share of total seats available at public Subsidy Reliant institutions fell almost exactly as steeply $(38.4 \%)$ as did the number of members of this category $(40.4 \%)$. The decline of the public Subsidy Reliant institution therefore seemed to constitute a meaningful erosion of student opportunity over time.

What became of these public Subsidy Reliant institutions? Figure 5 reports category membership for public institutions that belonged to the Subsidy Reliant group in 2005 and appeared in each year of the study. This subsample is smaller than the total size of the public Subsidy Reliant group in 2005 because some institutions did not report data for all years. By limiting our analysis to institutions that appeared in all years, however, we can ensure that we followed a consistent sample over time. As this figure indicates, most Subsidy Reliant publics that changed categories became Vulnerable. In 2005, there were almost no Vulnerable publics. Only $0.7 \%$ of all public institutions fell into the Vulnerable category. By 2013, there were dozens of Vulnerable public institutions, comprising 9.5\% of all public institutions in the sample.

Almost all of these newly Vulnerable publics had been Subsidy Reliant a few years before. A few fortunate public institutions-particularly those in populous, prosperous states such as Georgia, Massachusetts, and Texas-managed to move into the Smaller Typical Universities category. Institutions in this group enjoyed some stability in their operations. However, Smaller Typical Universities offered students less of a good value-with tuition bearing a higher share of educational spending - than did Subsidy Reliant institutions. Total available opportunity therefore shrunk slightly with as many as 19 formerly Subsidy Reliant institutions becoming Larger Typical Universities.

Even more concerning, many Subsidy Reliant institutions became Vulnerable. This growth in the lowest-value sector of U.S. higher education was alarming but widespread. By 2013, more than twice as many institutions (represented in Figure 5) had become Vulnerable as had become Smaller Typical Universities. What is more, even some public institutions that briefly moved into the Typical Smaller University category eventually fell into the Vulnerable group, as indicated by changes in the two groups from 2011 to 2013 (see Figure 5).

This transformation of large numbers of Subsidy Reliant publics into Vulnerable institutions has profound consequences for student opportunity. Subsidy Reliant institutions provide a racially diverse group of students with access to good value seats. In particular, Black and Native American students find opportunities at Subsidy Reliant institutions. As campuses that were once Subsidy Reliant became Vulnerable, however, the students who enrolled there found that their seats were no longer as valuable as they once were. Tuition rose while spending held steady or fell, making the seat 
sharply less valuable. As this happened, the number of Subsidy Reliant publics-the institutions that provided good value seats to a racially diverse group of students-feel steeply from what it had been in 2005.

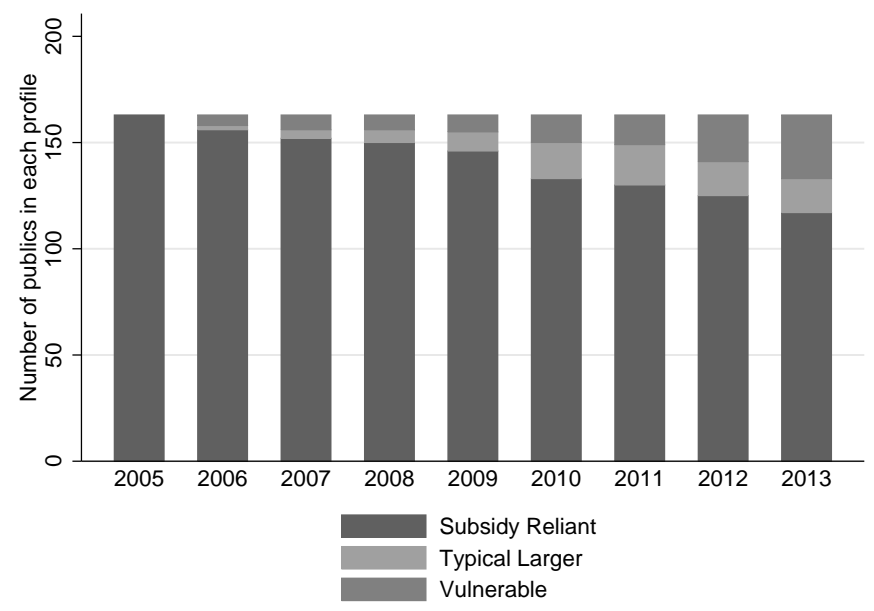

Figure 5. Change over time in percentage of public institutions that were Subsidy Reliant in 2005.

\section{Discussion}

This paper explores the apparent paradox of rising higher education participation and growing social inequality in the U.S. We argue that there is a crucial organizational dimension to this paradox: the mixture of available higher education institutions changed over time. The U.S. higher education system is famously differentiated and it has long been known that underrepresented students enroll disproportionally in less-selective and lower-resourced institutions. This study furthers our understanding of this process by quantifying the declining number of good value institutions that serve marginalized students.

Our LPA mapped institutional inequality along four dimensions, yielding a seven-category schematic for understanding institutions in the U.S. Three categories-Multiversities, Elite and Super Elite institutions-provide good value seats but serve relatively few students. There are few institutions in these categories, and all practice selective admissions. Only Subsidy Reliant institutions provide broad opportunity by practicing nonselective admissions and providing good value seats. What is more, the racial demographics of Subsidy Reliant institutions show that they are vital sites of opportunity for students of color, especially for Black and Native American students. While graduation rates overall are low, so are the gaps in completion rates between Black and White students, suggesting that Subsidy Reliant institutions make contributions to educational equity beyond admitting a diverse group of students.

Over time, however, the number of public Subsidy Reliant institutions has declined precipitously—likely due to the retreat of direct government support-making these opportunities more difficult for students to find. There were fewer good value seats in 2013 than there were in 2005. In this way, the U.S. system continues to enroll ever more students while providing only limited opportunity for an affordable education that leads to a better, more fulfilling life.

Our analysis confirms the commonly held belief that the American higher education system is under strain. The rise of Vulnerable public colleges and universities demonstrates the deterioration of the overall value of available seats in the system. This basic realization has led others to call for radical reform of colleges and universities as organizations, such as "unbundling" the university (Carey 2016). We are resistant to those calls. Archibald and Feldman (2017), two prominent U.S.-based economists of higher education, convincingly argue that educational quality is an important driver of cost increases in U.S. higher education. On the whole, students (and other contributors) are paying more for their education, but they are also getting more. Over time, the education provided by the 
average U.S. institution is becoming more elaborate thanks to costly investments in technology, skilled instructors, and cutting-edge facilities. Archibald and Feldman further claim that bundling these services on campus, rather than pricing them separately, likely achieves economies of scope. While costs are rising, total costs might rise even faster at an "unbundled" university than at one that pursues multiple activities simultaneously. Because unbundling would reduce economies of scope, students who attended unbundled campuses likely would experience a poor value education.

We agree with the basic outlines of Archibald and Feldman (2017) argument, but add that value is not just about the efficient delivery of educational services. Value also derives from the proportion of educational services that are borne by the consumer (students) in the form of tuition fees. Public divestment has resulted in rapid tuition increases, leading a substantial number of seats to shift from what we consider to be good to dubious value, as documented in Figure 5. Chronic divestment has resulted in a system that is underfunded, relative to the social return to higher education (McMahon 2018). This is a form of market failure reflecting government activity, in which insufficient social investment places high and uneven burdens on students. Given that the vast majority of students are locked out of the most desirable seats by selective admissions, decline in the value of accessible inventory raises serious question about system equity and stratification. Students can go somewhere but-save for the fortunate few who secure admission to a highly selective institution - they tend to pay more and get less in return because most of their educational options are low-value Vulnerable institutions.

As outlined in the Introduction, we argue that this state of affairs-defined by broad access but deteriorating value-is likely to erode the assumptions that undergird a high participation system. Higher education requires public trust (Margsinon 2012). Insofar as a high participation system rests upon a social rather than an economic basis, the decision to enroll reflects a widely held assumption about how people ought to behave rather than a rational calculation about maximizing personal utility. Participation is a social expectation. This social expectation is only sustainable in the long run if decent value opportunities are available to most students. Students must perceive that they are getting something in order to maintain the trust that undergirds a high participation system. If it becomes clear that higher education involves rising tuition fees and few good value seats, however, it is unclear how long this state of affairs can persist. Why would citizens maintain faith in a system that does not fulfill its promises of social mobility and a better life?

While it seems logical to speculate along these lines, we think this may be the wrong question. Indeed, we do not suggest that the high participation system of the U.S. is in any way fragile. We doubt that large numbers of students will stop enrolling in the short-run in part because there are few attractive employment options for individuals without some higher education and training and in part because participation is a social expectation. However great are the gaps between the value of seats in the U.S. system, attending higher education is almost always preferable to not participating. Trust may falter even as participation remains high.

A better question than why students continue to enroll despite shaken trust, then, may be why this state of affairs persists at all. If rising participation and growing inequality threaten to undercut trust in higher education, do they create trust in something else? Here we enter the realm of academic speculation, but we do so, we believe, in way that is informed and responsible. We suggest that the contradictions of U.S. higher education may provide continued political cover for those who wish to divest public funds from the enterprise. The malfunctions of U.S. higher education allow elected officials to divert funds from the sector in a way that both exacerbates inequities and cements ties with a core group of voters. In other words, U.S. higher education policy and practice likely reflect goals that are ancillary to the expansion of access and opportunity, and are instead rooted in broader political shifts within the country.

One plank in support of this argument is the way in which higher education is funded in the U.S. The political scientist Mettler (2011) argued that the way governments fund enterprises like higher education invites precisely this kind of political problem. Funding is "submerged" and therefore 
invisible to the average citizen, while the problems with the system are obvious in the form of high tuition and uncertain outcomes. As a result, the ills of government are widely known and its benefits easily missed. Extrapolating from Mettler, it seems likely that citizens will question the value of higher education without exploring the extent to which public policy has undercut that value. Indeed, there is some evidence from public polling that this is already happening, especially among self-identified "conservative" voters (Pew 2017). If our assumption is correct, policymakers who wish to defund higher education can do so without much cost to themselves because public anger will be directed at institutions, not the government.

A second plank in support of our argument is the way in which the negative effects of institutional inequality are targeted. The current U.S. higher education system seems to harm some students far more than others. Indeed, as we have shown, access to good value seats in the U.S. is stratified by race. Exposing students from racial and ethnic minority groups to low-value higher education at higher rates than White students is likely to further the agenda of the political actors who defunded higher education in the first place. The political scientist Abramowitz (2018) argues that the U.S. body politic is sharply divided between those who think the cultural changes of recent decades-a racially diverse population, the centrality of knowledge and education to economic and social life, growing urbanization, and so on-are positive and those who are resentful of these shifts. Resentful voters and politicians are disproportionately White, and tend to air their views in the form of racial resentment. As the historian Anderson (2016) has demonstrated, there is a long tradition in the U.S. of White racial resentment being expressed through legitimate public institutions such as law enforcement, political parties, and regulation. Rather than exposing the violence and contradictions of White resentment, the use of legitimate channels has served to normalize it. White resentment thereby becomes just another plank in the bundled identity of "conservatives" in the U.S. Even voters who may not be overtly skeptical of higher education or greater racial equality may find themselves supportive of officials who espouse such policies if the voter and candidate share other positions (Mason 2018).

Viewed in this way, the de-funding of public higher education in the U.S. becomes an end in itself, a means of repurposing government to punish a sector that many White voters resent because it is enmeshed in broader cultural changes they view unfavorably (Abramowitz 2018). Resentful White voters and their elected representatives may seek to de-fund higher education both because it is education and because it serves-however imperfectly-a racially diverse group of students. De-funding higher education therefore signals an agenda shared by reactionary policymakers and voters. Public divestment is not a means of balancing budgets or making tough fiscal choices, but is itself the goal. Punishing a disfavored sector becomes a rationale for governing and seeking reelection.

Such policies may erode trust in higher education, but they are likely to build trust between a narrow coalition of voters and politicians by signaling shared cultural practices. Indeed, there is some precedent for such practices. U.S. states with larger Black populations were less likely to accept generous federal subsidies to expand Medicaid, a health insurance program for low-income residents, suggesting that some politicians would rather refuse resources than see those funds benefit Black Americans (Grogan and Park 2017). It does not take a great leap of logic to imagine the politics of higher education following a similar path. As has been the case in the past (e.g., Thelin 2011), then, the provision of access to higher education in the U.S. may have less to do with higher education itself than with other political priorities in which higher education becomes enmeshed.

Of course, the shifting relationship between institutions and governments does not have uniform consequences on all campuses. Institutions with access to other revenue streams are likely to weather government divestment far more easily than do their Subsidy Reliant counterparts. After all, the number of public Subsidy Reliant institutions has declined far more steeply than has membership in any other category.

Given the implications for large numbers of individual students, the stakes of ongoing expansion of institutional inequality are high. Widening institutional inequality almost certainly means growing inequality of access and outcomes. We therefore encourage state governments, which bear the primary 
responsibility for funding U.S. higher education, to reinvest in Subsidy Reliant institutions. To be sure, reinvestment in all public institutions would be a welcome contribution to student opportunity. However, beginning with the institutions that provide the most opportunity for underserved students seems a sensible start to a campaign of public reinvestment.

\section{Conclusions}

The study of stratification in higher education has typically taken several approaches. One is stratification of access through patterned exclusion. Another is stratification in access, or the patterned sorting of students to institutions of varying status. The third is stratification of experiences, which considers patterned differences in student's social and educational experiences. The fourth is stratification of outcomes, or patterned differences in the social and economic returns to higher education. Each of these approaches provides a different way to probe the extent to which educational systems create, reproduce, or reduce social inequality. With the exception of expansion of enrollments, each of the approaches identified above tends to assume the organizational dynamics in the field of educational organizations are more or less fixed; the inventory of higher education today is assumed to be the inventory in the future. Relatively few studies consider how the quantity and quality of available seats shifts over time.

Among these four approaches, our study best fits with the second, stratification in access. We show that underserved students - in this case students who identify as racial minorities in the United States-are concentrated in less selective, lower-resourced institutions. In this regard, our study adds additional information to a phenomenon that is well-established; namely, that marginalized students enroll at disproportionately high rates in less selective and lower-resourced institutions. We extend this body of research, however, by considering changes to the field over time. Our study also analyzes the shifting composition of seats available to students in the system. By using federal data to categorize and classify all four-year colleges and universities in the country, we are able to show that the quantity of lower value seats has increased relative to the quantity of good value seats in the system. We further show that marginalized students, especially those who identify as Black and Native American, have the greatest exposure to these field-level changes because the institutions that have done the most to serve underserved students have become scarcer. We argue that adding a level of analysis that considers the mixture of high and low value places within higher education systems will enhance research on educational stratification.

The policy implications of our study are at once clear and imprecise. Efforts to improve the experiences and outcomes of marginalized students are underway in the United States. Findings from this study suggest that such efforts may be necessary but insufficient. Without addressing the underlying dynamics that have eroded the number of Subsidy Reliant institutions, it may be difficult to adequately improve educational practices. Proposals from the center-right of the American political spectrum have called for offering more vocationally-oriented qualifications, often to be delivered by for-profit providers. Echoing scholars such as Cottom (2017), we are skeptical that such proposals will expand opportunity to good-value higher education. Such non-traditional programs have a poor track record, especially when it comes to student debt accrual and repayment.

Voices on the left of the American political spectrum have advocated for policies that would establish universal free tuition in U.S. higher education. We have no ideological objections to free tuition-for example, we are unconcerned that it may be inefficient-but nevertheless enter two concerns. The first is that the association between social equity and free tuition internationally is weak. To be sure, the equitable Nordic countries do not charge tuition, but tuition is also at or near 0 for public in many highly inequitable countries. We propose that zero-tuition finance schemes may be a dependent variable whose outcomes are shaped by other social factors, rather than an independent variable that drives social equity. Our second concern is that free tuition policies address one aspect of value (how much the student pays) but not the other (how much education a student is getting). It is conceivable that free tuition programs will not include a massive infusion of public investment 
in the higher education system. Were this to be the case, free tuition could easily result in reduced spending and stripped down educational programs. As with unbundling proposals discussed above, our analysis does not support bare bones educational programs as the solution to student value and opportunity.

Consistent with our analysis, we argue that policy to improve value and opportunity in higher education should increase the inventory of accessible, good-value seats within the system. We think this would be most straightforwardly achieved through sharp increases in direct government support. Our field level approach to analyzing stratified opportunity in the U.S. higher education system suggests that fading subsidies and growing tuition dependence among the institutions that offer broad access to marginalized students is a contributor to inequitable opportunity. Direct government reinvestment in Subsidy Reliant institutions could arrest this constriction of student opportunity. Enhancing subsidies at accessible institutions may be the surest way to expand opportunity to good value higher education for all students in the system.

Author Contributions: Both authors contributed to the conceptualization, execution, and writing of this study. Funding: This research received no external funding.

Acknowledgments: The authors thank Kim Watts for her editorial assistance.

Conflicts of Interest: The authors declare no conflicts of interest.

\section{References}

Abramowitz, Alan I. 2018. The Great Alignment: Race, Party Transformation, and the Rise of Donald Trump. New Haven: Yale University Press.

Allen, Danielle. 2016. Education and Equality. Chicago: University of Chicago Press.

Anderson, Carol. 2016. White Rage: The Unspoken Truth of Our Racial Divide. New York: Bloomsbury.

Archibald, Robert B., and David H. Feldman. 2011. Why Does College Cost So Much? New York: Oxford University Press.

Archibald, Robert B., and David H. Feldman. 2017. The Road Ahead for America's Colleges and Universities. New York: Oxford University Press.

Barringer, Sondra N. 2016. The Changing Finances of Public Higher Education Organizations: Diversity, Change, and Discontinuity. In Research in the Sociology of Organizations. Edited by Elizabeth Popp Berman and Catherine Paradeise. London: Emerald, vol. 46, pp. 223-63.

Belkin, Douglas. 2016. Georgetown Offers Preferred Admissions to Descendants of Slaves Sold in 1838. Wall Street Journal. Available online: https://www.wsj.com/articles/georgetown-offers-preferred-admission-todescendants-of-slaves-sold-in-1838-1472745309. (accessed on 15 September 2018).

Brand, Jennie E., and Yu Xie. 2010. Who Benefits Most From College? Evidence for Negative Selection in Heterogeneous Economic Returns to Higher Education. American Sociological Review 75: 273-302. [CrossRef] [PubMed]

Breneman, David W. 1994. Liberal Arts Colleges: Thriving, Surviving or Endangered? Washington, DC: Brookings Institution Press.

Cantwell, Brendan. 2016. The New Prudent Man: Financial-Academic Capitalism and Inequality in Higher Education. In Higher Education, Stratification, and Workforce Development: Competitive Advantage in Europe, the U.S., and Canada. Edited by Sheila Slaughter and Barrett J. Taylor. Dordrecht: Springer, pp. 173-92.

Cantwell, Brendan. 2018. Broad Access and Steep Stratification in the First Mass System: High Participation in the United States of America. In High Participation Systems of Higher Education. Edited by Brendan Cantwell, Simon Marginson and Anna Smolentsiva. New York: Oxford University Press, pp. 227-65.

Cantwell, Brendan, Simon Marginson, and Anna Smolentsiva. 2018. High Participation Systems of Higher Education. New York: Oxford University Press.

Carey, Kevin. 2016. The End of College: Creating the Future of Learning and the University of Everywhere. New York: Riverhead Books. 
Chetty, Raj, David Grusky, Maximilian Hell, Nathaniel Hendren, Robert Manduca, and Jimmy Narang. 2017a. The Fading American Dream: Trends in Absolute Income Mobility Since 1940. Science 356: 398-406. [CrossRef] [PubMed]

Chetty, Raj, John N. Friedman, Emmanuel Saez, Nicholas Turner, and Danny Yagan. 2017b. Mobility Report Cards: The Role of Colleges in Intergenerational Mobility. No. w23618. Cambridge, MA, USA: National Bureau of Economic Research.

Cottom, Tressie McMillan. 2017. Lowerd Ed: The Troubling Rise of For-Profit Colleges in the New Economy. New York: The New Press.

Dale, Stacy, and Alan B. Krueger. 2011. Estimating the Return to College Selectivity over the Career Using Administrative Earnings Data. No. w17159. Cambridge, MA, USA: National Bureau of Economic Research.

Desrochers, Donna M., and Steven Hurlburt. 2014. Trends in College Spending: 2001-2011. Washington, DC: American Institutes for Research.

Douglass, John Aubrey. 2000. The California Idea and American Higher Education: 1850 to the 1960 Master Plan. Stanford: Stanford University Press.

Fligstein, Neil. 2001. The Architecture of Markets: A Sociologist of Twenty-First Century Capitalist Societies. Princeton: Princeton University Press.

Fligstein, Neil, and Doug McAdam. 2012. A Theory of Fields. New York: Oxford University Press.

Friedland, Roger, and Robert R. Alford. 1991. Bringing Society Back in: Symbols, Practices, and Institutional Contradictions. In The New Institutionalism in Organizational Analysis. Edited by Walter W. Powell and Paul J. DiMaggio. Chicago: University of Chicago Press, pp. 232-66.

Geiser, Chistian. 2013. Data Analysis with MPlus. New York: The Guilford Press.

Grogan, Colleen M., and Sunggeun Park. 2017. The Racial Divide in State Medicaid Expansions. The Journal of Health, Politics, Policy and Law 42: 539-72. [CrossRef] [PubMed]

Harris, Michael. S. 2013. Understanding Institutional Diversity: ASHE Higher Education Report 39:3. San Francisco: Jossey-Bass.

Labaree, David F. 1997. Public Goods, Private Goods: The American Struggle Over Educational Goals. American Educational Research Journal 34: 39-81. [CrossRef]

Ladson-Billings, Gloria. 1998. Just What is Critical Race Theory and What's it Doing in a Nice Field Like Education? International Journal of Qualitative Studies in Education 11: 7-24. [CrossRef]

Lau, Yan, and Harvey S. Rosen. 2016. Are Universities Becoming More Unequal? The Review of Higher Education 39: 479-514.

Leslie, Larry L., Sheila Slaughter, Barrett J. Taylor, and Liang Zhang. 2012. How do Revenue Variations Affect Expenditures Within Research Universities? Research in Higher Education 53: 614-39. [CrossRef]

Marginson, Simon. 2006. Dynamics of National and Global Competition in Higher Education. Higher Education 52: 1-39. [CrossRef]

Margsinon, Simon. 2012. The "Public" Contributions of Universities in an Increasingly Global World. In Universities and the Public Sphere: Knowledge Creation and State Building in the Era of Globalization. Edited by Brian Pusser, Ken Kempner, Simon Marginson and Imanol Orodika. New York: Routledge, pp. 7-26.

Marginson, Simon. 2016a. High Participation Systems of Higher Education. The Journal of Higher Education 87: 243-71. [CrossRef]

Marginson, Simon. 2016b. The Dream is Over. Berkeley: The University of California Press.

Marginson, Simon. 2016c. Global Stratification in Higher Education. In Higher Education, Stratification, and Workforce Development: Competitive Advantage in Europe, the U.S., and Canada. Edited by Sheila Slaughter and Barrett J. Taylor. Dordrecht: Springer, pp. 13-34.

Marginson, Simon. 2017. Limitations of Human Capital Theory. Studies in Higher Education. [CrossRef]

Mason, Lilliana. 2018. Uncivil Agreement: How Politics Became our Identity. Chicago: University of Chicago Press.

Masyn, Katherine E. 2013. Latent Class Analysis and Finite Mixture Modeling. In The Oxford Handbook of Quantitative Methods. Edited by Todd D. Little. New York: Oxford University Press, pp. 551-611.

McMahon, Walter W. 2009. Higher Learning, Greater Good: The Private and Social Benefits of Higher Education. Baltimore: The Johns Hopkins University Press.

McMahon, Walter W. 2018. The Total Return to Higher Education: Is There Underinvestment for Economic Growth and Development? The Quarterly Review of Economics and Finance. [CrossRef] 
Mettler, Suzanne. 2011. The Submerged State: How Invisible Government Policies Undermine American Democracy. Chicago: University of Chicago Press.

Morphew, Christopher C. 2009. Conceptualizing Change in the Institutional Diversity of U.S. Colleges and Universities. The Journal of Higher Education 80: 243-69. [CrossRef]

Muthen, Linda K., and Bengt O. Muthen. 2011. Mplus User's Guide. Los Angeles: Muthen and Muthen.

National Center for Education Statistics [NCES]. 2017. Digest of Education Statistics; Washington, DC: U.S. Department of Education.

Nichols, Andrew H., and Denzel Evans-Bell. 2017. A Look at Black Student Success: Identifying Top- and Bottom-Performing Institutions. Washington, DC: The Education Trust.

Pew Research Center [Pew]. 2017. Sharp Partisan Divisions in Views of National Institutions. Washington, DC: The Pew Foundation.

Piketty, Thomas. 2014. Capital in the Twenty-First Century. Cambridge: Belknap.

Piketty, Thomas, and Emmanuel Saez. 2003. Income Inequality in the United States, 1913-1998. The Quarterly Journal of Economics 118: 1-41. [CrossRef]

Posselt, Julie, Ozan Jaquette, Rob Bielby, and Michael N. Bastedo. 2012. Access Without Equity: Longitudinal Analyses of Institutional Stratification by Race and Ethnicity, 1972-2004. American Educational Research Journal 49: 1074-111. [CrossRef]

President's Commission on Slavery and the University. 2018. Report to President Teresa A. Sullivan. Charlottesville: The University of Virginia.

Schofer, Evan, and John W. Meyer. 2005. The Worldwide Expansion of Higher Education in the Twentieth Century. American Sociological Review 70: 898-920. [CrossRef]

Slaughter, Sheila, and Larry Leslie. 1997. Academic Capitalism. Baltimore: The Johns Hopkins University Press.

Slaughter, Sheila, and Gary Rhoades. 2004. Academic Capitalism and the New Economy. Baltimore: The Johns Hopkins University Press.

State Higher Education Executive Officers [SHEEO]. 2018. State Higher Education Funding: FY 2017. Boulder: SHEEO.

Taylor, Barrett J. 2016. The Field Dynamics of Stratification Among U.S. Research Universities: The Expansion of Federal Support for Academic Research, 2000-2008. In Higher Education, Stratification, and Workforce Development: Competitive Advantage in Europe, the U.S., and Canada. Edited by Sheila Slaughter and Barrett J. Taylor. Dordrecht: Springer, pp. 59-79.

Taylor, Barrett J., and Christopher C. Morphew. 2013. Institutional Contributions to Financing Students in U.S. Higher Education: Trends in General Subsidies, 1987-2007. In Student Financing of Higher Education: A Comparative Perspective. Edited by Donald E. Heller and Claire Callender. New York: Routledge Press, pp. 225-51.

Thelin, John R. 2011. A History of American Higher Education. Baltimore: The Johns Hopkins University Press.

Thomas, Scott L. 2003. Longer-Term Economic Effects of College Selectivity and Control. Research in Higher Education 44: 263-99. [CrossRef]

Trow, Martin. 1974. Problems in the Transition From Elite to Mass Higher Education. Berkeley: The Carnegie Commission on Higher Education.

Webber, Douglas A. 2014. The Lifetime Earnings Premia of Different Majors: Correcting for Selection Based on Cognitive, Noncognitive, and Unobserved Factors. Labour Economics 28: 14-23. [CrossRef]

Weisbrod, Burton A., Jeffrey P. Ballou, and Evelyn D. Asch. 2008. Mission and Money: Understanding the University. New York: Oxford University Press.

Wilder, Craig S. 2013. Ebony and Ivy: Race, Slavery, and the Troubled History of America's Universities. New York: Bloomsbury Press.

Winston, Gordon C. 1999. Subsidies, Hierarchy and Peers: The Awkward Economics of Higher Education. The Journal of Economic Perspectives 13: 13-36. [CrossRef]

Zietsma, Charlene, and Thomas B. Lawrence. 2010. Institutional Work in the Transformation of an Organizational Field: The Interplay of Boundary Work and Practice Work. Administrative Science Quarterly 55: 189-221. [CrossRef]

(C) 2018 by the authors. Licensee MDPI, Basel, Switzerland. This article is an open access article distributed under the terms and conditions of the Creative Commons Attribution (CC BY) license (http://creativecommons.org/licenses/by/4.0/). 